\title{
THE EFFECTS OF BANANA STEM (Musa paradisiaca var. sapientum) EXTRACT ON HISTOPATHOLOGIC GASTRIC OF RATS INDUCED BY INDOMETACHIN
}

\author{
Rochmah Kurnijasanti, Arninda Alfiani Putri \\ Department of Veterinary Basic Medicine \\ Faculty of Veterinary Medicine, Universitas Airlangga
}

\begin{abstract}
ABSTRAK
Penelitian ini bertujuan untuk mengetahui pengaruh pemberian ekstrak batang pisang ambon (Musa paradisiaca var. sapientum) untuk mencegah kerusakan lambung dan mengamati histopatologi lambung tikus yang diinduksi oleh indometasin. Penelitian ini menggunakan 30 tikus jantan usia 8-12 minggu memiliki berat 150 gram. Mereka dipilih secara acak dan dibagi menjadi lima kelompok. Kelompok kontrol negatif ( $\mathrm{K}$-) diberi $0,5 \mathrm{ml} \mathrm{CMC} \mathrm{Na}$ 0,5\% selama 9 hari dan 0,5 ml minyak jagung diberikan pada hari ke-10. Kelompok kontrol positif $(\mathrm{K+})$ diberi $0,5 \mathrm{ml}$ CMC Na 0,5\% selama 9 hari dan diberi Indometasin Emulsi $5 \mathrm{mg} / 0,5 \mathrm{ml} / 150 \mathrm{~g}$ $B W$ sekali pada hari ke-10, dan kelompok lain diberi ekstrak batang pisang ambon untuk (P1) $20 \mathrm{mg} / 150 \mathrm{~g} \mathrm{BW,} \mathrm{(P2)} 40 \mathrm{mg} / 150 \mathrm{~g}$ $B W$ dan (P3) $80 \mathrm{mg} / 150 \mathrm{~g} \mathrm{BW}$ selama 9 hari. Setelah itu, mereka diberi Indometachin Emulsi $5 \mathrm{mg} / 150 \mathrm{~g}$ BW sekali pada hari ke-10. Setiap spesimen diproses dan diamati perubahan histopatologi lambungnya. Scoring mukosa epitel erosi dan perdarahan, sebagai data kualitatif dianalisis dengan uji Kruskal-Wallis dan dilanjutkan dengan menggunakan uji Z. Hasil penelitian menunjukkan bahwa ekstrak batang pisang ambon secara signifikan berkurang di lambung epitel mukosa dan erosi hemoragik yang disebabkan oleh Indometasin ( $p<0,05)$. (FMI 2016;52:246-250)
\end{abstract}

Kata kunci: anti-inflamasi, ekstrak batang pisang ambon (Musa paradisiaca var sapientum), Indometachin, lambung

\begin{abstract}
This research aims to find out the administration effect of Ambon banana stem extract (Musa paradisiaca var. sapientum) to prevent gastric damage and observe histopathology of rat's gastric induced by indomethacin. This research used 30 male rats age 8-12 week having 150 gram weight. They were selected randomly and divided into five groups. Negative control ( $K$-) was given $0.5 \mathrm{ml} \mathrm{CMC} \mathrm{Na}$ $0.5 \%$ for 9 days and $0.5 \mathrm{ml}$ corn oil was given on 10th. Positive control $(\mathrm{K}+$ ) was given $0.5 \mathrm{ml} \mathrm{CMC} \mathrm{Na} 0.5 \%$ for 9 days and then given Indomethacin emultion $5 \mathrm{mg} / 0.5 \mathrm{ml} / 150 \mathrm{~g} \mathrm{BW}$ once on 10th day, and the other groups were given Ambon banana stem extract for (P1) $20 \mathrm{mg} / 150 \mathrm{~g} \mathrm{BW,} \mathrm{(P2)} 40 \mathrm{mg} / 150 \mathrm{~g} \mathrm{BW}$ and (P3) $80 \mathrm{mg} / 150 \mathrm{~g} \mathrm{BW} \mathrm{for} 9$ days. Afterwards, they were given Indometachin emultion $5 \mathrm{mg} / 150 \mathrm{~g} \mathrm{BW}$ once on 10th day. Each gastric specimen was processed and histopathological changes were observed. Scoring of mucosa epithelium erosion and hemorrhagic, as qualitative data, was analyzed by Kruskall-Wallis test and continued by using $Z$ test. The result shows that Pisang Ambon's stem extract reduce significantly in gastric mucosa epithelium erosion and hemorrhagic induced by Indomethacin $(p<0.05) .($ FMI 2016;52:246-250)
\end{abstract}

KeywordS: anti inflammatory, pisang ambon's stem extract (Musa paradisiaca var. sapientum), Indometachin, Gastric

Correspondence: Rochmah Kurnijasanti, Department of Veterinary Basic Medicine, Faculty of Veterinary Medicine, Universitas Airlangga, Campus C, Mulyorejo, Surabaya

\section{INTRODUCTION}

Based on the data published by World Health Organization (WHO), Indonesia was ranked fourth in the number of gastritis patients after United States of America, United Kingdom and Bangladesh (BPPK Depkes 2008). The disease is caused due to the two important factors of gastric, namely aggressive and defensive factor. Cell partial has role as the aggressive factor to secreting gastric acid, while on the other hand, defensive factor includes the formation and secretion of mucus within mucosa that play important role in gastric mucosal resistance. If one factor is in imbalance condition between aggressive and defensive factor, it will cause various gastric disorders (Julius 1992). Some of the gastric disorders are caused by the use of NonSteroidal Anti Inflammatory Drugs (NSAID) that causes gastric mucosal damage with two mechanisms by directly irritating gastric epithelium and inhibiting prostaglandin. Indomethacin is one of NSAIDs that is mostly used (Kurnijasanti et al 2014).

The use of indomethacin has side effects on the gastric, which is erosion of gastric mucosal that eventually forms ulcer and complication such as gastric perforation and bleeding. Indomethacin shows the strongest toxicity effect on stomach through inhibition of cyclo-oxygenase-1 (COX-1) enzyme. The function of COX-1 enzyme is as gastric cytoprotection and controlling the production of prostaglandin to protect gastric from 
acidic state (Manggau 2010). The inhibition of COX-1 enzyme causes the decrease of prostaglandin. The decrease of prostaglandin causes declining protection on gastric mucosal and makes pathogenic bacteria easily to invade (Indraswari et al 2004). Indomethacin is also assumed to have topical effect damaging mucosa of small intestine and gastric (Petruzalli et al 2007, Venneman et al 2006). Therefore, the administration of indomethacin becomes the model inducer of damage within gastrointestinal tract, particularly the stomach.

Pisang Ambon (Ambon banana) is a plant with many benefits, which one of them is useful as the traditional medicine by using its stem. The stem of Pisang Ambon is used as the utilization of natural ingredients to lessen the usage of synthesis medicine. The stem has active compounds, namely flavonoid and tannin, which have roles in preventing side effect of indomethacin. Flavonoid of pisangambon's stem can be functioned as antioxidant and anti-inflammation. Flavonoid works by slowing down the process of inflammation through inhibitory effect on the metabolism pathway of arachidonic acid and forming prostaglandin. On the other hand, tannin has role in ceasing bleeding (Arifin 2006).

\section{MATERIAL AND METHODS}

\section{Research sites}

This research was taken at Faculty of Veterinary Medicine, Universitas Airlangga. The process of making pisang ambon's stem was taken at Laboratory of Basic Medicine, Faculty of Veterinary, Universitas Airlangga. The conservation and administration of treatment on the experimental animals were taken at the animal cages of Faculty of Veterinary, Universitas Airlangga. The process of making preparation and value scoring of histopathological changes were taken at Department of Veterinary Pathology, Faculty of Veterinary, UniversitasAirlangga.

\section{Equipment and materials}

Scalpel, scissors and tweezers were used as the surgical equipment. Digital scales, rod stirrer, measuring cups, vortex, rotator vacuum evaporator, and Erlenmeyer were used as the extraction equipment. Paraffin mould, waterbath, microtomy, object glass, and cover glass were used as histopathology equipment. Microscope, stomach probes, banana stem, Indomethacin, corn oil, sterile distilled water, CMC Na $0.5 \%$, ethanol $96 \%$, stomach, $10 \%$ formalin, xylol, Haematoxylin solution, a solution of eosin, paraffin were materials used in the preparations for histopathology. Rat foods which in the form of chicken fillet, drinking water, wood shavings were used as the base enclosure.

\section{Stem extraction banana ambon}

The initial stage of making extract of banana was by slicing $10 \mathrm{~kg}$ of banana stem into small pieces, then drying by putting them in a room temperature that is not exposed to direct sunlight, and then the banana stems were milled to a powder. Powder was obtained as much as $1.2 \mathrm{~kg}$. The powder was put into the jar and soaked with $96 \%$ ethanol for three days. Once it was done, filtration was done using filter paper. The next process was the filtrate screening of the soaked stem with $96 \%$ ethanol and then concentrated them in a rotary evaporator (vacuum rotary evaporator) at a temperature of $40^{\circ} \mathrm{C}-50^{\circ} \mathrm{C}$ and speed of $40 \mathrm{rpm}$, in order to separate the ethanol 96\% from the compounds. Thick extract have been successfully withdrawn from that.

\section{Research implementation procedures}

This study used 30 rats, which were selected randomly. The rats, then, were divided into five groups: negative control $(\mathrm{K})$, which was given $0.5 \mathrm{ml} / \mathrm{head} /$ orally of $\mathrm{CMC} \mathrm{Na} 0,5 \%$ for 9 days and on the 10th day they were given corn oil $0.5 \mathrm{ml} / \mathrm{head}$ orally. Positive controls (K + ) were given $0,5 \% 0.5 \mathrm{ml} / \mathrm{head} /$ orally of CMC Na for 9 days and, on the 10th day, they were given indomethacin emulsion at a dose of $5 \mathrm{mg} / 0.5 \mathrm{ml} / 150 \mathrm{~g} \mathrm{BW}$ rats orally. P1 group was given Ambon banana stem extract at a dose of $20 \mathrm{mg} / 150 \mathrm{~g} \mathrm{BW}$ rats orally for 9 days. Later, on the 10th day, they were given indomethacin emulsion at a dose of $5 \mathrm{mg} / 0.5 \mathrm{ml} / 150 \mathrm{~g} \mathrm{BW}$ rats orally. P2 group was given Ambon banana stem extract at a dose of $40 \mathrm{mg} / 150 \mathrm{~g} \mathrm{BW}$ rats orally for 9 days. Later, on the 10th day, they were given indomethacin emulsion at a dose of $5 \mathrm{mg} / 0.5 \mathrm{ml} / 150 \mathrm{~g} \mathrm{BW}$ rats orally. P3 group was also given Ambon banana stem extract at a dose of $80 \mathrm{mg} / 150 \mathrm{~g} \mathrm{BW}$ rats orally for 9 days, and then they were given indomethacin emulsion at a dose of $5 \mathrm{mg} / 0.5 \mathrm{ml} / 150 \mathrm{~g} \mathrm{BW}$ rats orally. On the 11th day, the rats were sacrificed by means of cervical dislocation, and then rats were dissected and separated from their stomach. The organ was added to formalin solution $10 \%$, and then histopathology preparations are made.

\section{Histopathological preparations examination}

Histopathological preparations examination was done by using a microscope at 400x and 100x magnification to 5 different fields of view for each sample/slide. For the histological assessment, specimens were assed according to the criteria of modified $\mathrm{Li}$, et al, 2014. The histological scoring for epithelial erosion was assessed $0-3$. The scoring of no pathological changes was zero 
(0), epithelial erosion for less than $1 / 3$ of field of view was scored with one (1), epithelial erosion for $1 / 3-2 / 3$ of field of view was scored with two (2), and epithelial erosion for more than whole field of view was scored with three (3). The histological scoring hemorrhagic was scored as follows: no pathological changes was scored with zero (0), hemorrhagic for less $25 \%$ of field of view was scored with one (1), hemorrhagic for $26 \%$ to $50 \%$ of field of view was scored with two (2), hemorrhagic for $51 \%$ to $75 \%$ of field of view was scored with three (3), and hemorrhagic for more scored than whole field of view was scored with four (4).

\section{RESULTS}

\section{Ephitellium erosion}

The results of the analysis by using the Kruskal-Wallis test, shows significant results with $\mathrm{p}=0.006(\mathrm{p}<0.05)$. This shows that treatment has different influences significantly, so it was preceded with Z-test. The comparison between administration using the $\mathrm{Z}$ test results that the positive control $(\mathrm{K}+)$ and $\mathrm{P} 1$ show no significant difference to $\mathrm{P} 2$, while the negative control (K -) and P3 show a highly significant difference to the positive control $(\mathrm{K}+)$. The result can be seen in Table 1 .

Table 1. Results of gastric mucosal epithelial erosion score, induced by indomethacin in the various treatment of ambon banana stem

\begin{tabular}{cc}
\hline Administration & Mean Rank \\
\hline K- & $6,83^{\mathrm{b}}$ \\
K+ & $22,50^{\mathrm{a}}$ \\
P1 & $20,83^{\mathrm{a}}$ \\
P2 & $15,33^{\mathrm{ab}}$ \\
P3 & $12,00^{\mathrm{b}}$ \\
\hline
\end{tabular}

Based on the result and observation of fundic part of rats gastric, the highest epithelial erosion severity shown in positive control $(\mathrm{K}+)$ characterized by ulcer up to lamina propia. While groups in which treated with ambon banana stem, P1 showed more severity than P2 and P3 shown with the existence of epithelial erosion. $\mathrm{P} 2$ and P3 groups were showing rupture in gastric mucous epithel. The condition of normal gastric mucous epithel was shown in negative control (K-). Histopathology result of gastric mucous epithel erosion is shown in Fig. 1.

\section{Hemorrhage}

Result on analysis by means of Kruskall-Wallis test indicates significantly different findings in which $\mathrm{p}=$ 0.0001 ( $p<0.05)$. By using $\mathrm{Z}$ test, positive control $(\mathrm{K}+)$ and $\mathrm{P} 1$ do not reflect the significant differences toward
$\mathrm{P} 2$, whereas negative control (K-) and P3 show significant differences toward positive control $(\mathrm{K}+)$. These results are listed in Table 2 .

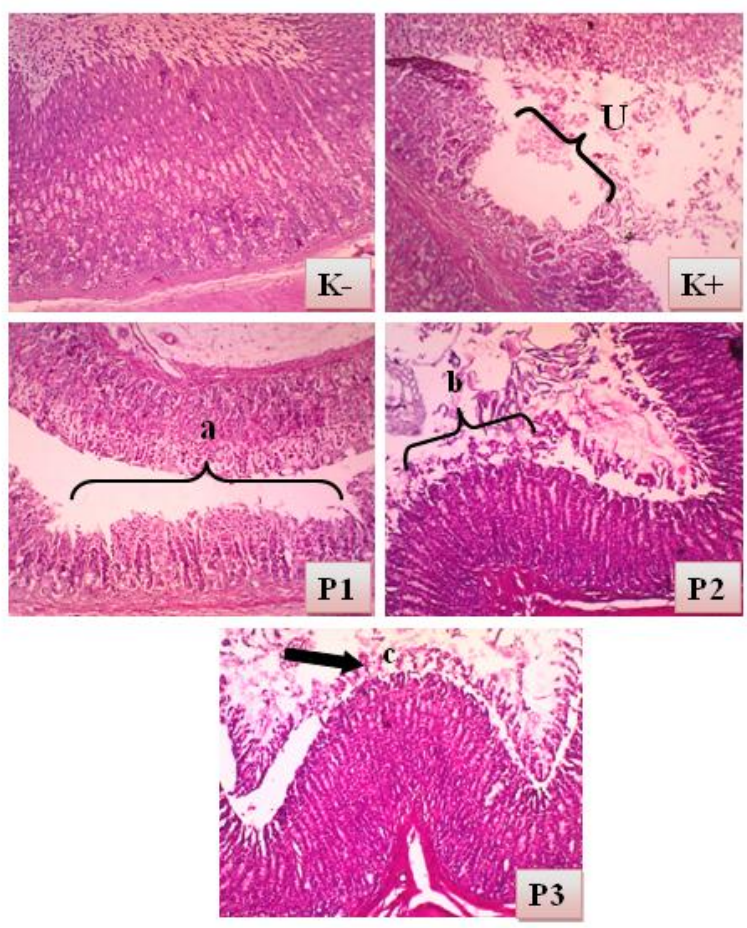

Fig. 1. Histopathology of gastric mucosa epithelial erosion. Stain: Haematoxylin and Eosin magnifation x100 with optilab ${ }^{\circledR}$ viewer. Ket: normal gastric condition (K-), ulceration (u) $(\mathrm{K}+)$, epithelial erosion (a) (P1), gastric mucosa epithelial rupture (b dan c) (P2 dan P3).

Table 2. Result of gastric hemorrhage score induced by Indomethacin in various administration of Pisang Ambon's stem extract

\begin{tabular}{cc}
\hline Administration & Mean Rank \\
\hline K- & $5,50^{\mathrm{b}}$ \\
K+ & $24,17^{\mathrm{a}}$ \\
P1 & $20,83^{\mathrm{a}}$ \\
P2 & $15,50^{\mathrm{ab}}$ \\
P3 & $11,50^{\mathrm{b}}$ \\
\hline
\end{tabular}

Based on the result of observation and assessment histopathology gastric of rats obtained the result shows the highest hemorrhagic of gastric mucosa interstitial on positive control $(\mathrm{K}+)$ and followed $\mathrm{P} 1$. Normal condition of gastric mucosa on negative control (K-). P2 and P3 hemorrhagi on gastric mucoa interstitial decline. The 
results of histhology hemorrhagic on gastric of rats are shown in the Fig. 2.

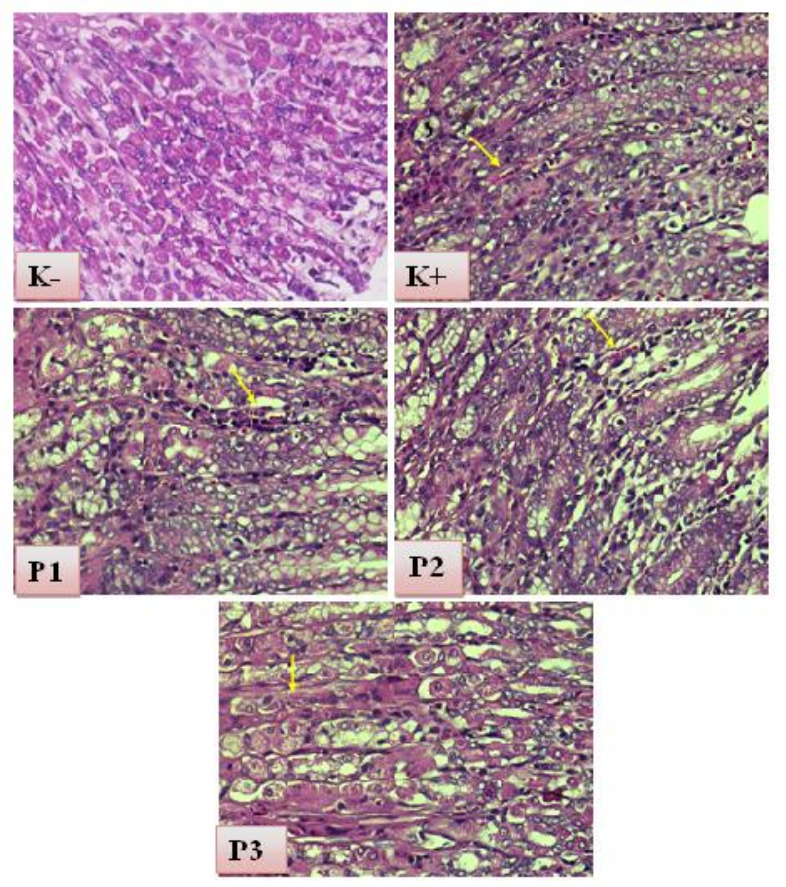

Fig. 2. Histopathology of gastric mucosa epithelial erosion. Stain: Haematoxylin and Eosin magnifation x100 with optilab ® viewer. K+ there are is hemorrhage that almost all mucous, P1 shows hemorrhage at most compared to the $\mathrm{P} 2$ and P2, P2 shown to decrease hemorrhage on mucous, P3 shows hemorrhage at least. The arrow indicates hemorrhage.

\section{DISCUSSION}

\section{Epithelial erosion}

Gastrointestinal tract is very susceptible towards the interference from defensive factors, which maintain the structure of the mucosa and aggressive factors that damage the mucosal defense. The results showed the highest level of epithelial erosion on $(\mathrm{K}+)$. These results are quite similar to the statement of Soylu et al (2008), that indomethacin inhibits the activity of the enzyme COX-1. Inhibition of COX-1 by indomethacin will reduce prostaglandin formation of gastric mucosa. Prostaglandin is produced by the gastric mucosa that has cytoprotective effects. If prostaglandin production is inhibited, it will cause interference on gastric mucosal barrier, inhibition of gastric mucosal epithelial regeneration process and excessive gastric acid secretion, thereby increasing the acidity is likely to cause damage and inflammation in the gastric mucosa.
P1 group shows significantly different results with a positive control $(\mathrm{K}+)$. This suggests that the dose of 20 mg extract is not effective to inhibit erosion of the gastric mucosa epithelium. These results are consistent with the statement of Shargel et al (2005), in which the administration of oral medications cause reduced bioavailability of the drug. It is also caused by the use of indomethacin at a dose of $30 \mathrm{mg} / \mathrm{kg}$, which is effective in causing acute inflammation (Indraswari et al 2004). P2 and P3 group shows the lowest results after the negative control $(\mathrm{K})$ with the average results of 15.33 and 12.00. These results indicate the dose of $40 \mathrm{mg}$ and $80 \mathrm{mg}$ extract of banana stem is a good dose to prevent erosion of the mucosal epithelium, compared to a dose of $20 \mathrm{mg}$. However, the P3 group shows the best results with the average results are lower than $\mathrm{P} 2$. This shows that the protection against gastric mucosal epithelial is better with an increased dose of banana stem extract and flavonoids derived from banana stem, which function as antioxidants to prevent erosion of the gastric mucosal epithelium. These results are consistent with the statement of Kumaran \& Karunakaran (2007), that flavonoids, especially on microvascular endothelium, function to reduce the occurrence of hypermeability and inflammation. Some flavonoids can inhibit the release of arachidonic acid by blocking the track of cyclooxygenase (COX) and lipoxygenase, resulting in lower levels of prostaglandins and leukotrienes (mediaor inflammation) and will decrease inflammatory reactions. Flavonoids also work by inhibiting the histidine decarboxylase enzyme, so that histamine synthesis is inhibited. Histamine is an important mediator in allergic inflammatory disease. Therefore, the banana stem will inhibit inflammatory reactions due to histamine gastritis (Prabowo 2007).

\section{Hemorrhage}

According to research has been conducted, positive control $(\mathrm{K}+)$ induced by indomethacin shows the highest rate of hemorrhage compare to other administration groups which mean is 22,83 . Along with this, Indraswari (2004) argues that indomethacin will work by inhibiting COX-1 and COX-2 enzyme, but more effective to inhibit COX-1. In addition, COX-1 responsible to maintain the stomach surface lining in good condition, enhance bicarbonate and mucus production as well as establish prostaglandin of acute inflammation. The inhibition of COX-2 could cure inflammation symptoms, whereas inhibition of COX-1 could damage or get erosions to gastric mucosa. This erosion of gastric mucosa may cause acute gastric bleeding ulcer. The lowest hemorrhage results occur to negative control (K-) which are not inducted by indomethacin with mean 4.50. Result of administration to negative control (K-) shows that there is no 
hemorrhage in several repetition. $\mathrm{P} 1$ group shows no significant differences to positive control $(\mathrm{K}+)$. This reveal that indomethacin absorption in digestive system specifically stomach is $90 \%$, so that administration of $20 \mathrm{mg}$ of banana stem extract still not effective to inhibit hemorrhage of gastric mucosa interstitial (Katzung 1998).

Group P2 and P3 confirms the lowest results of hemorrhage with mean 16.17 and 12.83 , which indicates that P3 is the most appropriate administration to inhibit hemorrhage due to lower score than P2. It also has been argued by Odukoya et al (2009) that pisang ambon stem consist of $4.38 \%$ tannin. Tannins are astringent, plant polyphenols responsible to bind and precipitate or shrink proteins, whose function to stop bleeding. The more protein precipitated by tannin, the more thromboxane synthesis A2 and facilitate the thrombocytes performs Adenosine Diphosphat (ADP). Moreover, Adenosine Diphosphat (ADP) and thromboxane A2 activate the activated thrombocytes to adhere one another. This may cause the enhancement of platelet aggregation, so that the huge platelet clot in blood vessel will decrease.

\section{CONCLUSION}

According to research and discussion, the result reveals that the extract of batang ambon's stem (Musa paradisiaca var. sapientum) affects on the degradation of mucosal epithelium erosion and white rats gastric hemorrhage induced by Indomethacin.

\section{REFERENCES}

Arifin, A.S. 2006. Materi Pokok Kimia Organik Bahan Alam. Edisi ke 3. Jakarta Karunia. Hal: 11-16.

BPPK DEPKES RI, Riset Kesehatan Dasar (Riskesdas) 2007: Laporan Nasional 2007, 2008, Badan Penelitian dan Pengembangan Kesehatan Departemen Kesehatan Republik Indonesia, Jakarta, hal 277-278, 281-283.

Indraswari, I., U. Kalsum, dan Sudjari. 2004. Pengaruh Pemberian Temulawak pada Lambung Tikus yang Mengalami Ulkus Peptikum Akibat Induksi Indometasin. Jurnal Kedokteran Brawijaya. Malang. 100 (2): 96.
Julius. 1992. Patogenesis Tukak Peptik. Cermin Dunia Kedokteran. 79: 9-13.

Katzung, B. G. 1998. Farmakologi Dasar dan Klinik. Edisi VI. Jakarta: EGC, pp: 305-320.

Kumaran, A dan R. J. Karunakaran. 2007. In vitro antioxidant activities of methanol extracts of five Phyllanthus species from India. LWT-food Science and Technology. Vol 40 Pp: 344-52.

Kurnijasanti, R., D.K. Meles., S. A, Sujarwo., T. Juniastutik., I.S. Hamid. 2014. Buku Ajar Farmakoterapi dan Toksikologi, Cetakan I. Penerbit Duta Persada Press. Surabaya: Fakultas Kedokteran Hewan Universitas Airlangga. Hal: 70.

Li, W. F., J.H Ding., F. Ting., M.H. Hui., Y. Huan., F.N. Xiao. 2013. Protective Effect of Chelerythrine Against Ethanol-Induced Gastric Ulcer in Mice. China. Science Direct Elsevier. Pp:64.

Odukoya, O.A., Sofidiya, M.O., Ilori, O.o., Gbedodo, M.O., Ajadotuigwe, J.O., Olaleye, O.O. 2009. Hemorrhoid Therapy with Medicinal Plants: Astringency and Inhibition of Lipid Peroxidation as Key Factors. International Journal of Biological Chemistry, Pp: 111-118.

Petruzelli M, M. Vacca., A. Moschetta., R.C. Sasso., G. Palasciano., K.J.V. Erpecum., P. Portincassa. 2007. Intestinal mucosal damage caused by non-steroidal anti-inflammatory drugs: Role of bile salts. Clinical Biochemistry 40: 503-510.

Prabowo, N. A. 2007. Pengaruh Air Rebusan Daun Salam (Syzygium polyanthum) Terhadap kerusakan Histologi Lambung Mencit yang Diinduksi Aspirin. Skripsi. Universitas Negeri Solo. Fakultas Kedokteran.

Shargel, L., A. Yu, dan S. Wu. 2005. Biofarmasetika dan Farmakokinetika Terapan. Edisi kedua. Airlangga University Press. Surabaya. Pp: 167-187.

Soylu, A., C. Dolapciouglu., K. Dolay., A. Cilitas., N. Yasar., M. Kalayci., H. Alis., N. Server. 2008. Endoscopic and Histopathological Evaluation of Acute Gastric Injury in High-dose Acetaminophen and Non Steroidal Anti-Inflammatory drug Ingestion with Sucidal Intent. World Journal of Gastroenterology Press. Pp: 6075-6076.

Venneman NG, Petruzulli M, van Dijk, verheem A, Akkermans LMA, Krocse ABA, van Erpecum KJ, 2006. Indomethacin distrupts the protective effect of phosphatidylcholine agaist bile salt-induced ileal mucosa injury. Eur J Clin Invest 36: 105-112. 